\title{
Pollution Haven Hypothesis and the Role of Dirty Industries in Turkey's Exports
}

\author{
Elif Akbostanc1, G.İpek Tunç, Serap Türüt-Aşık \\ Department of Economics, \\ Middle East Technical University \\ Ankara 06531 Turkey
}




\title{
Pollution Haven Hypothesis and \\ the Role of Dirty Industries in Turkey's Exports*
}

\author{
Elif Akbostanc1, G.İpek Tunç, Serap Türüt-Aşık \\ Department of Economics \\ Middle East Technical University \\ Ankara 06531 Turkey
}

Pollution haven hypothesis argues that the industries that are highly pollution intensive i.e. dirty industries, have been migrating from developed economies to the developing world. It is argued that the environmental concerns of the developed economies caused them to enact strict environmental regulations, which have increased the cost of production of the dirty industries at home. On the other hand, the developing countries with their low wages and lax environmental regulations have been attractive alternative producers in these sectors. At the same time this migration is also beneficial for developing countries that are in need of financial resources for industrial development. Consequently, developing countries provide pollution havens for dirty industries. In this process while the dirty industries have been migrating to the developing countries, the developed countries also have become net importers of these sectors. In this study the pollution haven argument for Turkey, for 1994-1997 period is examined. The study focuses on the pollution haven hypothesis from trade perspective by looking at the manufacturing industry data at 4-digit ISIC detail by using the panel data approach. It is found that exports increase as the dirtiness of the industries increases, providing some evidence for the pollution haven hypothesis.

JEL Classification: F18, N50, F14

Corresponding Author: Elif Akbostanc1

Middle East Technical University,

Department of Economics, 06531, Ankara, Turkey

Tel: $+90-312-2103079$

Fax: $+90-312-2101244$

E-Mail: elifa@metu.edu.tr

\footnotetext{
* This study has been supported by the METU Scientific Research Project Fund (BAP-2003-04-03-01). We are grateful to Erol Taymaz for his help in data gathering and insightful comments. An earlier version of this paper was presented in the ERC/METU International Conference in Economics, VII.
} 


\section{Introduction}

Less developed countries' industrialization process has accelerated in the second half of the twentieth century and has developed in such a way that a number of industrial activities formerly located in developed countries have moved into these countries. These industries not only include traditional labor intensive industries such as textiles and clothing but also heavy industries like steel, petrochemicals, fertilizers and paper, some of which are causing high rates of pollution. Today, most of the less developed countries are faced with high levels of industrialization and growth on the one hand and social and environmental problems on the other hand. Meanwhile, the developed countries have started to specialize in new technology-based industries such as biotechnology, information-processing and microelectronics. The overall trend toward rapid growth of traditional industries in less developed countries seems likely to accelerate in the late 1990s. As a result, such structural changes could lead to increased environmental pressures in these countries, unless clean and efficient technologies are adopted on a large scale (Park and Labys, 1998).

Differences among countries in environmental standards and costs cause relocation of economic activity especially dirty industries from strictly controlled countries to those with few or no standards by creating 'pollution havens' for developed countries. That is, pollution havens occur when dirty industries move from countries with stringent environmental regulations to countries with weak regulations. According to Eskeland and Harrison (2003), the pollution haven hypothesis is best seen as a corollary to the theory of comparative advantage: as pollution control costs begin to matter for some industries in some countries, other countries should gain comparative advantage in those industries, if pollution control costs are lower there.

The pollution haven hypothesis assumes that environmental regulations have a strong effect on industrial location and that differential regulations between two countries will at minimum induce specialization and probably significant capital movements to the country with weaker regulations. Therefore, according to this hypothesis both the industrial production structure and trade patterns of countries should be affected. The share of dirty industries is expected to increase while that of clean industries to decline over time in pollution havens. Also, since the pollution havens are becoming larger producers of the dirty industries, the share of dirty industries is expected to increase in the exports of a pollution haven.

In the literature there are numerous studies examining the role of dirty industries in trade patterns of different countries. ${ }^{1}$ These studies can be classified into two basic groups; where in the first group there are studies that use gravity models of bilateral trade. In those models, trade is determined by indicators of country

\footnotetext{
${ }^{1}$ To have a wider perspective on the issues related to trade and environment, see Copeland and Taylor (2003), Huang and Labys (2002) and Jaffe et al. (1995) which present detailed literature surveys on the topic.
} 
size (GDP, population and land area) and of the distance between the pair of countries in question (physical distance as well as dummy variables indicating common borders, linguistic links etc.). In the other group trade effect is examined within the framework of Heckscher-Ohlin (H-O) model, where the environment is treated as a factor of production that is directly used for agricultural and industrial production as an input. The H-O theorem, if extended in this context, suggests that countries that have lax environmental standards will, under a free trade regime, specialize in pollution intensive goods. In order to test this hypothesis the literature uses HeckscherOhlin-Vanek (HOV) theorem, which states that a country's relative factor intensity is revealed through the factor services embeded in that country's trade flows (Appleyard and Field, 2001). Therefore, it could be interpreted that the countries which have comparative advantage in dirty industries are also expected to be major pollution intensive exporters.

In terms of empirical results, we can describe the literature on trade effects of pollution havens as diverse and contradictory. Among the gravity model examples we can cite van Beers and van den Bergh (1997), Xu (2000), Grether and de Melo (2002) and Khan (2003). van Beers and van den Bergh (1997) test the hypothesis that countries having strict environmental regulations experience relatively low levels of exports and relatively high levels of imports. Environmental policy stringency measures are used in a trade flow equation based on bilateral trade flows to investigate a cross-country data set of 21 OECD countries for 1992. In their model, they use three different dependent variables (total bilateral trade flows, bilateral trade flows in pollution intensive sectors and bilateral trade flows in pollution intensive sectors that are non-resource based); and GDPs, land areas, populations and strictness of environmental regulations of the countries, the distance between the countries and dummy variables for being adjacent countries, being a member of EC and EFTA as explanatory variables. The authors can find no significant effect of environmental policy stringency on dirty export flows and this is explained by the fact that most dirty industries are resource based. On the other hand a significant negative effect of environmental policy stringency is found for non-resource based activities.

In another study Xu (2000) examines whether more stringent domestic environmental policies reduce the international competitiveness of environmentally sensitive goods (ESG). Initially to provide time series evidence of the changing trade pattern of ESGs across countries over time, the author uses a dataset of annual trade flows of 134 ESGs disaggregated at the four-digit level of the SITC from 1965 to 1995 for 34 countries, which accounts for nearly 80 per cent of world exports and trade of ESGs in 1995 . He includes 25 of the 29 OECD countries (Czech Republic, Hungary, Iceland and Turkey are excluded) and major East Asian developing economies. The time series evidence indicates that there are no systematic changes in trade patterns of ESGs 
since the 1970's, despite the introduction of more stringent environmental regulations in most of the developed countries since then. This observation is tested econometrically by modifying the basic log-linear version of gravity equation to include the variables for import tariffs. He includes Bangladesh, Brazil, Bulgaria, China, Egypt, Finland, Germany, India, Ireland, Kenya, Korea, the Netherlands, Nigeria, Pakistan, the Philippines, South Africa, Switzerland, Thailand, Trinidad Tobago and Tunisia in his sample. The model is estimated using cross-section data in 1990 with a unique set of comparative environmental stringency indices developed by the World Bank. First, whether countries with higher stringency of environmental regulations lower their exports of ESGs and/or non-resource-based ESGs and secondly whether new trade barriers emerge to offset the trade effects of more stringent environmental policy are tested. The results reject these two hypotheses, suggesting that countries with more stringent environmental regulations do not reduce their exports of ESGs and/or nonresource-based ESGs, and that new trade barriers do not emerge to offset the trade effects of more stringent environmental policy in any statistically significant way.

On the other hand Grether and de Melo (2002) present evidence on the production and international trade flows in five heavily polluting industries for 52 countries (30 less developed and 22 developed countries) over the period 1981-98 by using 3-digit ISIC production and trade data. In their study, the panel estimation of a gravity model of bilateral trade shows that compared with other industries, dirty industries have higher barriers to trade (except for non-ferrous metals) and therefore, the authors conclude that there is only moderate support for the pollution haven hypothesis.

In another attempt to search for the pollution haven hypothesis trade effect, Kahn (2003) tests whether the greatest dirty trade growth in the U.S. has taken place with poorer non-democratic nations. By using bilateral gravity trade regressions and four-digit SIC manufacturing industry data, he finds that between 1958 and 1994, the average pollution content of U.S. manufacturing imports has fallen. Poor nations and non-democratic nations are not major exporters of pollution intensive goods to the U.S. However one piece of evidence that supports the pollution haven hypothesis is that relative to South America, Asia and Europe, Africa's exports to the U.S. are the most pollution intensive. He concludes that shipping costs may be playing a key role in why the evidence for the pollution haven hypothesis is weak as he finds that the elasticity of trade with respect to pollution content for light industries is much higher than for heavy industries.

Among HOV type models, we can cite Tobey (1990), Grossman and Kruger (1991) and Wilson, Otsuki and Sewadeh (2002). In his influential paper, Tobey (1990) tests the hypothesis that environmental regulations have altered the pattern of trade in goods produced by dirty industries. A set of eleven resource endowments, 
including capital, labor, land, primary solid fuels, minerals, oil and gas, for the year 1975 is used to explain net exports of the most polluting industries under the HOV model. Under different specifications of HOV model two approaches are taken to conduct empirical tests. The first approach involves the inclusion of a qualitative variable in the model to represent the stringency of pollution control measures and the second approach does not include the qualitative variable. He finds that the qualitative variable describing the stringency of environmental controls in a group of 58 high income, middle income and low income countries fails to contribute to the determination of their net exports of the most pollution-intensive commodities. He concludes that the magnitude of environmental expenditures in countries with stringent environmental policies is not sufficiently large to cause a noticeable effect.

Grossman and Krueger (1991) test whether pollution abatement costs in 3-digit SIC manufacturing industries in the U.S. affect imports from Mexico in 1987. They investigate whether and to what extent the sectoral patterns of U.S. foreign investment in Mexico and of Mexican exports to the U.S. are affected by the laxity of environmental regulations in Mexico as compared to the stricter enforcement of controls in the U.S. They find that competitive advantages created by lax pollution controls in Mexico play no substantial role in motivating trade and investment flows. The findings of this study suggest that relative factor supplies govern the pattern of trade between Mexico and its neighbors to the North. The asymmetries in environmental regulations and enforcement between the U.S. and Mexico play at most a minor role in determining intersectoral resource allocations.

Wilson, Otsuki, and Sewadeh (2002) address the issue of how to link trade agreements to the environment, from a developing country perspective. They try to find whether environmental regulations affect exports of dirty goods in 24 countries (6 OECD and 18 non-OECD countries) between 1994 and 1998. Based on a Heckscher-Ohlin-Vanek model and using a non-linear two stage least squares method, they found that, if country heterogeneity such as enforcement of environmental regulations is controlled for, more stringent environmental standards imply lower net exports of metal mining, nonferrous metals, iron and steel and chemicals. This negative relationship between the stringency of environmental standards and the exports may imply a possible trade-off between trade expansion and improvements in environmental standards. If less developed countries do not place an emphasis on environmental quality then this could result in "race to the bottom" implying that pollution may become more concentrated in less developed countries.

In this study, the impact of dirty industries on Turkish exports will be explored. In order to classify dirty industries we use the State Institute of Statistic's Industrial Waste Statistics. In the literature there are basically 
two methods for classification of dirty industries. The first method measures the pollution content by use of pollution abatement and control expenditures (PACE), which capture the producer's cost burden of pollution regulation. This approach identifies dirty industries as those with the highest PACE per unit of output. According to OECD (2003) data in Turkey pollution abatement costs as a sum constitute $1.1 \%$ of GDP. However pollution abatement cost data for Turkey at the industry level are not available. The second measure of pollution intensity directly measures emissions for estimating the pollution intensity of production (Bommer; 1998). An example of that is the U.S. Environmental Protection Agency's Toxic Release Inventory which tracks emissions of more than 200 toxic chemicals from U.S. manufacturing firms. However, for Turkey this kind of data is not available either. The only available data are the amount of waste produced by firms at the ISIC revision 2, in 4-digit detail. Yet, toxic content of this waste is unavailable as well. Therefore, based on this data we construct pollution indices and we also try to overcome the shortcoming of the lack of toxic content of waste data by using Linear Acute Human Toxicity Index as an additional source (Hettige, Martin, Singh and Wheeler, 1995).

Using available data on Turkish manufacturing industry we analyze the impact of dirty industries on the exports of Turkey by using a panel of 67 sectors for 1994-1997 period. Availability of data restricts the scope of the study. In the literature the only study with regards to Turkey is on the impact of environmental regulations on exports of the leather industry (Larson et al, 2002). Leather, a highly pollution-intensive industry, is one of the traditional sectors of the Turkish economy. It is found that in the leather industry a $2-6 \%$ increase in total production costs due to water effluent controls, will result in a fall about $1.4-11.4 \%$ of total production and $2.3-$ $45 \%$ of total exports if export price is fixed. With international price adjustments this result falls from $45 \%$ to $7 \%$.

The current study is the only one that is known today which explores the Turkish case. The paper is constructed as follows: the next section is about the model and econometric methodology. The details with regards to the data set and construction of pollution indices are also discussed in the next section. Estimation results are presented in section 3 . Finally, section 4 concludes the paper.

\section{Model, Econometric Methodology and Data Set}

\subsection{Model and Econometric Methodology}

In this section we are going to model Turkey's sectoral manufacturing industry exports to the rest of the world. The general format of the model is basically the same as the export demand functions that could be seen 
in the theoretical and applied literature with some modification to account for the environmental impact. The general form used in this study has the following structure:

$$
X=f\left(P_{X} / P_{M}, E, Y^{*}, H, P I\right)
$$

where $\mathrm{X}$ is the exports of Turkey, $\mathrm{P}_{\mathrm{X}} / \mathrm{P}_{\mathrm{M}}$ is the terms of trade, $\mathrm{E}$ is the effective exchange rate, $\mathrm{Y} *$ is the foreign income, $\mathrm{H}$ is the Herfindahl index ${ }^{2}$ measuring the concentration in industries which is used here to control for market condition variations among different sectors. Finally, PI is a measure of pollution intensity index, which will establish the relationship between dirty industries and trade. In order to turn this model into an econometric one we have used a log-linear structure as follows:

$$
x_{i t}=\alpha+\beta_{1} \text { tot }_{i t}+\beta_{2} e_{t}+\beta_{3} y_{t}^{*}+\beta_{4} H_{i t}+\beta_{5} P I_{i t}+\mu_{i}+v_{i t} \quad i=1, \ldots, N ; t=1, \ldots, T
$$

where lower case letters denote the $\ln$ of the same variable, tot is the $\ln$ of the terms of trade ratio $\mathrm{P}_{\mathrm{X}} / \mathrm{P}_{\mathrm{M}}$. In equation (2) we expect $\beta_{I}$ to be usually negative; as tot increases competitiveness of the home country declines and exports would fall. $\beta_{1}$ is also the relative price elasticity of exports in this model. Similarly, in general we would expect $\beta_{2}$ to be positive; as home currency depreciates competitiveness of the home country increases, and it measures the exchange rate elasticity of exports. $\beta_{3}$ is expected to be positive; as world income increases we would expect the demand for home country exports to increase. The Herfindahl index H takes values that range from 0 for a perfectly competitive market, to 1 for a monopolistic market. Therefore, a negative sign for $\beta_{4}$ would indicate that as the level of competitiveness increases in the market, the demand for exports increases as well. Finally, the sign of $\beta_{5}$ is our focus. If the level of dirtiness were a determinant of export performance, then we would expect this coefficient to be significant. Also according to the pollution haven hypothesis, dirty industries are moving away from the environmentally strict developed world to the environmentally lax developing world. Therefore, from the developing country perspective we would expect an increase in the

${ }^{2} \mathrm{H}=\sum_{\mathrm{i}=1}^{\mathrm{n}} \mathrm{s}_{\mathrm{i}}^{2}, \mathrm{H}$ is the Herfindahl index where $\mathrm{s}_{\mathrm{i}}$ is the market share of firms in a sector where there are $\mathrm{n}$ firms. By definition $0 \leq \mathrm{H} \leq 1$, and $\mathrm{H}=1$ indicates a monopolistic market structure whereas $\mathrm{H}=0$ is a perfectly competitive market. 
dirtiness of the exports if the pollution haven hypothesis were valid. The positive sign of $\beta_{5}$ would be counted as an evidence for the trade effect of the pollution haven hypothesis.

The disturbance term in equation (2) can be written as $u_{i t}=\mu_{i}+v_{i t}$. The disturbance term has two components, $\mu_{\mathrm{i}}$ are the unobservable individual effects and $v_{i t}$ are the idiosyncratic errors. The econometric literature on panel techniques focuses on how these unobserved effects are treated which determines the econometric technique that is going to be used in estimation. If $\mu_{\mathrm{i}}$ are treated as random, then it is called the random effects (RE) model, if $\mu_{i}$ are assumed to be fixed parameters to be estimated then it is called the fixed effects (FE) model. The random effects approach effectively puts $\mu_{\mathrm{i}}$ into the error term under the assumption that $\mu_{\mathrm{i}}$ are orthogonal to the dependent variable and uses a generalized least squares (GLS) analysis that accounts for the implied serial correlation in the error term $u_{i t}=\mu_{i}+v_{i t}$ (Wooldridge, 2002).

In this study we estimate Equation 2 by using both the $\mathrm{FE}$ and $\mathrm{RE}$ estimators. In terms of the FE estimators least squares dummy variables (LSDV) estimator that uses a matrix of individual dummies in the ordinary least squares (OLS) regression, and within estimator that uses deviations from time means are utilized. In terms of the RE estimators, the feasible generalized least squares (GLS) estimator is used. The GLS estimator replaces the variables by deviations from weighted time means. The outcome in this case depends on the choice of the weight; in this case we utilize two weights, one is calculated by using variances estimated from within and between estimations and the other is calculated by using the OLS estimation.

\subsection{Data Set}

The current study applies the above model to the Turkish manufacturing industry data in 4-digit International Standart Industrial Classicification (ISIC) Revision 2 detail. The study covers 1994-1997 period for 67 sectors. The chosen period is the only period that environmental waste data are available for Turkey, and availability of the data determined the scope of the study, as mentioned before. The data set used in the study is described in Table 1.

[ Insert Table 1 here]

For the pollution index, PI, we use different proxies that we construct by using the available pollution data. The data are taken from SIS for Turkish manufacturing industry and are in 4-digit ISIC Revision 2 detail. The only available data for Turkish manufacturing industry are the solid and liquid waste quantities. As mentioned before, there are different methods for measuring the pollution. However, for Turkey no information regarding different pollutants is available, and therefore we use waste output values to construct a pollution 
index. In order to make the pollution index comparable among industries, differences in size of the different industries need to be controlled. Therefore, the basic structure of the index takes the following form:

$$
\mathrm{PI}=\text { Waste output } / \text { Total manufacturing activity }
$$

The total manufacturing activity can be calculated by looking at different measures. Hettige, Martin, Singh and Wheeler (1995) suggest physical volume of output, shipment value, value added and employment as alternative choices. We use three different measures for total manufacturing activity:

1. Employment

2. Real value added

3. Real value of output

The solid waste (sw) and liquid waste (lw) indices therefore are calculated by using different denominators that are numbered as sw1, sw2, sw3, lw1, lw2 and $\mathbf{l w} 3$, where 1, 2 and 3 refer to the above measures as denominators respectively ${ }^{3}$. By using the solid waste and liquid waste indices we construct a weighted average index that represents a general measure for pollution. These averages are called pi1, pi2, and pi3; where again 1, 2 and 3 refer to the alternative measures of manufacturing activity.

Even though we refer pi1, pi2 and pi3 as pollution intensity indices, what we actually measure is solid and liquid waste intensity. An industry with large amounts of solid and/or liquid waste may not necessarily be releasing pollutants that are toxic. For example when we look at the ranking produced by our indices we see that processed food sectors are ranking high in terms of producing waste, but their waste is probably not as toxic as industrial chemicals sector. Therefore, the index that we construct may not be an exact measure of dirtiness of the manufacturing industries since we are unable to tell the level toxicity of waste produced by these sectors with the available data.

To correct this shortcoming we also construct alternative indices, which are called hpi1, hpi2 and hpi3 with the help of Linear Acute Human Toxic Intensity Index (LAHTI) that is calculated by Hettige, Martin, Singh and Wheeler (1995). LAHTI ranks the toxicological risk associated with particular chemicals released from a facility based on US Environmental Protection Agency’s Toxic Release Inventory for 1987 and Human Health and Ecotoxicity Database. LAHTI ranks the pollutant intensity according to risk associated with human health and terrestrial ecological damage. Assuming that the risk factor is the same across the countries and has not changed much through time we have used the ranking provided by LAHTI as a weight correcting for the

\footnotetext{
${ }^{3}$ The employment, value added, and output values are from SIS Annual Manufacturing Industry Statistics data base and the output and value added figures are in current TL values. These are converted into real values by using sectoral wholesale price index, where $1987=100$.
} 
differences in toxicity across different facilities. Therefore, we construct hpi1, hpi2 and hpi3, which are the LAHTI weighted indices. This weighting works as a filter and shows the polluting industries according to the risk attached to the toxic content of their waste.

[ Insert Figures 1, 2, 3 and 4]

Figures 1- 4 plot these alternative indices for $1997^{4}$. We can observe several points regarding these indices: First among the different measures of the denominator, indices constructed by using real value added show the highest variation. When we consider the solid waste indices (Figure 1) we see that three groups of high amounts of waste producing sectors step forward. The first group consists of sectors 3118 (sugar factories and refineries) and 3115 (manufacture of vegetable and animal oils and fats), the second group consists of 3710 (iron and steel basic industries) and 3720 (non ferrous metal basic industries), and finally 3511 (manufacture of basic industrial chemicals except fertilizers) and 3512 (manufacture of fertilizers and pesticides). In terms of the liquid waste (Figure 2) same groups apply but the ranking changes, and also we see the addition of 3210 (textiles) to the picture. As expected the average indices pil-pi3 plotted in Figure 3 combine Figure 1 and Figure 2. Figure 4 shows that when the average indices are weighted by LAHTI, then the picture changes radically. When we consider the toxicity factor, it appears that among the above-mentioned sectors only 3511, 3512, 3710 and 3720 remain as the highest polluting industries. These industries coincide with the dirty sectors that literature points to for different countries. ${ }^{5}$

\section{Estimation Results}

By using panel estimation techniques and the Turkish data, Equation 2 is estimated. The model is run by using alternative pollution indices as explained in the previous section. Considering the scope of this paper, we are going to present only three models. In all of these models pollution indices that are based on real value added are used since these indices are the ones that give the best results. The structure of the models does not change much when the other alternative indices are considered. Tables 2, 3 and 4 present estimation results for models 1,2 and 3 , respectively.

In the first two rows of the Tables 2, 3 and 4, LSDV estimations first with individual dummies and then with individual and time dummies are presented. This is the standard FE model estimation technique. Within groups estimations transform the dependent and explanatory variables by deviations from time means. Between

\footnotetext{
${ }^{4}$ To have detailed information on these indices and for further analysis of dirty industries in Turkey, see Akbostanc1, Tunç, and Türüt-Aşı1k (2004).

${ }^{5}$ See for example Xing and Kolstad (2002), Mani and Wheeler (1997) and Tobey (1990).
} 
group estimations replace the variables by the means of each individual; therefore, the data set is effectively reduced to the cross section observations. The next two estimation techniques are RE models, and both use GLS as the estimation method. The difference between the two techniques lies in the weights that are used when variables are time demeaned. In the first one the weights from within and between estimations are used and in the second one the weights from OLS estimation are used. Finally, in the last rows of the tables result of the maximum likelihood (ML) estimation is given in which the weights are obtained by iterating the GLS procedure.

[ Insert Table 2 here]

In model 1 the average pollution index pi2 is used. In general all the results show that the relative prices, tot, and the exchange rate, $e$, variables have significant coefficients and the signs turn out to be as expected. An increase in relative prices decreases the demand for exports and the depreciation of the domestic currency increases the demand for exports. In terms of the elasticities we can say that export demand is inelastic with respect to relative price. In most cases, the exchange rate elasticity of exports is less than one. However, depending on the estimation technique exchange rate elasticity of exports turns out to be greater than one if time dummies are used or the model is estimated by using time means (between groups estimation). The coefficient of the Herfindahl index variable $H$, is also significant and negative in all cases; therefore, we can conclude that increased levels of competition in industries encourages demand for exports. We also see that the coefficient of the pollution index pi2, is positive and significant. Therefore, we can say that Turkey exports more from the industries that produce relatively large amounts of waste. This can be taken as an evidence for the trade effect of the pollution haven hypothesis.

[Insert Table 3 here]

Similarly the results in Table 3 presenting model 2 are basically the same. The difference between models 1 and 2 is that in model 2 we replace the pollution index pi 2 by hpi2. In terms of the coefficients of the variables tot, $e$ and $H$ findings are the same. Similarly the coefficient of the pollution index is significant and positive when FE techniques are used. However, it doesn't seem to be significant when the model is estimated by RE techniques. Another difference is that the coefficient of the pollution index in model 2 is smaller than that of in model 1.

\section{[Insert Table 4 here]}

We also try to use the solid waste (sw) and liquid waste (lw) indices separately in Model 3 rather than using the average indices. The results of this experiment are presented in Table 4. When the solid waste and liquid waste indices are introduced into the model, we see that only the solid waste index turns out to be 
significant and similar results as in models 1 and 2 are found. We also see that the pollution index variable's coefficient is not significant when the RE model is used.

These results bring out the issue of which estimation technique we should take into consideration. In order to decide on this issue we carry out a specification test based on Hausman (1978) suggested by Baltagi (2001) to compare the two models. If the unobserved components of the error term of Equation 2 are not correlated with the explanatory variables, then the GLS estimator and within estimator will be equal to each other. If however, the unobserved components are correlated with the dependent variables then the GLS estimator will be biased and inconsistent. In order to carry out the specification test, an auxiliary regression that uses the GLS transformation on the variables and includes time demeaned explanatory variables as additional variables is run. Hausman's test in this case is equivalent to testing whether the coefficients of the timedemeaned variables are significant. The rejection would imply that using the RE model is not appropriate.

[Insert Table 5 here]

Table 5 summarizes the results of the specification test explained above. For all of the three models the test is rejected at $99 \%$ significance, which indicates that FE estimation techniques are more appropriate for our sample. Therefore, with greater confidence we could conclude that our results provide some evidence for the pollution haven hypothesis. The estimated models show that during the period that is considered, in the Turkish manufacturing sector as the dirtiness of the industries increases the demand for exports increases as well.

\section{Conclusion}

Pollution haven hypothesis argues that dirty industries flee from environmentally strict industrialized countries to the less developed economies which provide pollution havens for these industries with their lax environmental standards. If this hypothesis were valid, it would be expected that the trade flows of a pollution haven would be affected; industrial dirtiness should be a factor in determining the trade flows of the pollution haven.

This study explores this effect by examining Turkish manufacturing industry data for the period of 1994-1997. In order to measure industrial dirtiness, pollution indices based on industrial waste output data are developed. These indices are utilized to examine the role of dirty industries in the manufacturing trade of Turkey. In this study an export equation is expanded to include the pollution index, and estimated by using panel data estimation techniques. 
Estimation results indicate that pollution intensity of different industries seems to be a determinant of

Turkish exports. Estimated models show that in the period that is considered, as the dirtiness of the sectors increases the demand for Turkish manufacturing exports increases as well. Therefore it is possible to conclude that results of this study provide some evidence for the trade effect of the pollution haven hypothesis from the developing country perspective.

\section{References}

Akbostancı E., Tunç, İ. and Türüt-Aşık, S. (2004) Manufacturing Industry and Dirtiness: Turkey as a Pollution Haven ( in Turkish) Middle East Technical University Economic Research Center Working Paper.

Appleyard, D. R. and Field, A. J. Jr. (2001) International Economics, Fourth Edition, McGraw-Hill Higher Education

Baltagi, B. H. (2001) Econometric Analysis of Panel Data, Second Edition, John Wiley and Sons Ltd.

Bommer, R. (1998) Economic Integration and the Environment: A Political-Economic Perspective, Cheltenham: Edward Elgar.

Copeland, B. R. and Taylor, M. S. (2003) Trade, Growth and the Environment, NBER Working Paper No. 9823.

Eskeland, G. S. and Harrison, A. E. (2003) "Moving to Greener Pastures? Multinationals and the Pollution Haven Hypothesis", Journal of Development Economics, 70, 1-23.

Grether, J. M. and de Melo, J. (2002) "Globalization and Dirty Industries: Do Pollution Havens Matter?", http://www.unige.ch/ses/demelo/WorkProgress/

Grossman, G. M. and Krueger, A. B. (1991) "Environmental Impacts of a North American Free Trade Agreement", NBER Working Paper No. 3914.

Hausman, J. A. (1978) "Specification Tests in Econometrics", Econometrica, 46, 1251-1271.

Hettige, H., Martin, P., Singh, M., and Wheeler, D. (1995) "The Industrial Projection System“ World Bank Policy Research Working Paper No. 1431.

Huang, H. and Labys, W. C. (2002) "Environment and Trade: A Review of Issues and Methods", International Journal of Global Environmental Issues, 2(1-2), 100-160.

Jaffe, A. B., Peterson, S. R., Portney, P. R. and Stavins, R. N. (1995) "Environmental Regulation and the Competitiveness of U.S. Manufacturing: What Does the Evidence Tell Us?", Journal of Economic Literature, 33, 132-163.

Kahn, M. E. (2003) “The Geography of U.S. Pollution Intensive Trade: Evidence from 1958 to 1994”, $\underline{\text { Regional }}$ Science and Urban Economics, 33, 383-400.

Mani, M. and Wheeler, D. (1997) "In Search of Pollution Havens? Dirty Industry in the World Economy, 19601995", http://www.worldbank.org/research.

OECD (2003) Pollution Abatement and Control Expenditure in OECD Countries, ENV/EPOC/SE (2003) 1.

Larson, B. A., Nicolaides, E., Al Zu’bi, B., Sukkar, N., Laraki, K., Matoussi, M. S., and Zaim, K. (2002) “The Impact of Environmental Regulations on Exports: Case Study Results from Cyprus, Jordan, Morocco, Syria, Tunisia and Turkey “, World Development, 30(6), 1057-1072.

Park, S. H. and Labys, W. C. (1998) Industrial Development and Environmental Degradation: A Source Book on the Origins of Global Pollution, Cheltenham: Edward Elgar.

Tobey, J. (1990) "The Effects of Domestic Environmental Policies on Patterns of World Trade”, Kyklos, 43(2), 191-209.

van Beers, C. and van den Bergh, J. C. J. M. (1997) “An Empirical Multi-Country Analysis of the Impact of Environmental Regulations on Foreign Trade Flows”, Kyklos, 50(1), 29-46.

Wilson, J. S., Otsuki, T. and Sewadeh, M. (2002) "Dirty Exports and Environmental Regulation: Do Standards Matter to Trade?" The World Bank Policy Research Working Paper No. 2806.

Wooldridge, J. M. (2002) Econometric Analysis of Cross Section and Panel Data, Cambridge, Mass.: MIT Press.

Xing, Y. and Kolstad, C. D. (2002) "Do Lax Environmental Regulations Attract Foreign Investment?", Environmental and Resource Economics, 21, 1-22.

Xu, X. (2000), "International Trade and Environmental Regulation: Time Series Evidence and Cross Section Test", Environmental and Resource Economics, 17, 233-257. 
Table 1

\begin{tabular}{|c|c|c|}
\hline Variable & Description & Source \\
\hline $\mathbf{X}$ & $\begin{array}{l}\text { Value of Turkey's exports to the world in 4-digit } \\
\text { International Standart Industrial Classicification (ISIC) } \\
\text { Revision } 2 \text { code in US Dollars. }\end{array}$ & $\begin{array}{l}\text { State Institute of Statistics of Republic } \\
\text { of Turkey(SIS), Foreign Trade } \\
\text { Statistics. }\end{array}$ \\
\hline $\mathbf{P}_{\mathbf{X}}$ & $\begin{array}{l}\text { Export price index in 4-digit ISIC Revision } 2 \text { code. } \\
(1987=100)\end{array}$ & SIS, Foreign Trade Statistics. \\
\hline $\mathbf{P}_{\mathbf{M}}$ & $\begin{array}{l}\text { Import price index in 4-digit ISIC Revision } 2 \text { code. } \\
(1987=100)\end{array}$ & SIS, Foreign Trade Statistics. \\
\hline TOT & Terms of trade, defined as $\left(\mathrm{P}_{\mathrm{X}} / \mathrm{P}_{\mathrm{M}}\right) \times 100$ & \\
\hline $\mathbf{E}$ & $\begin{array}{l}\text { Nominal effective exchange rate. It is calculated as the } \\
\text { trade-weighted average of US Dollar, German Mark, } \\
\text { French Frank, British Pound, and Italian Lire exchange } \\
\text { rates. These five exchange rates are chosen by } \\
\text { considering the largest trade partners of Turkey in the } \\
\text { period of 1994-1997. }\end{array}$ & $\begin{array}{l}\text { Central Bank of Republic of Turkey } \\
\text { online database. } \\
\text { http://tcmbf40.tcmb.gov.tr/cbt.html }\end{array}$ \\
\hline $\mathbf{Y}^{*}$ & $\begin{array}{l}\text { World income proxy. It is calculated as a trade } \\
\text { weighted average of US, German, French, Italian and } \\
\text { British GDP in current US Dollars. Same trade weights } \\
\text { are used as in the calculation of E. }\end{array}$ & $\begin{array}{l}\text { World Bank World Development } \\
\text { Indicators. } \\
\text { http://devdata.worldbank.org/dataonline }\end{array}$ \\
\hline $\mathbf{H}$ & Herfindahl index in 4 digits ISIC Revision 2 code. & $\begin{array}{l}\text { SIS, Concentration in the Turkish } \\
\text { Manufacturing Industry. }\end{array}$ \\
\hline PI & Pollution Index. & $\begin{array}{l}\text { SIS, Manufacturing Industry Waste } \\
\text { Statistics }\end{array}$ \\
\hline
\end{tabular}

Table 2

Model 1: Modeling $x$ by using pi2

\begin{tabular}{|c|c|c|c|c|c|c|c|}
\hline & constant & tot & $e$ & $\boldsymbol{H}$ & pi2 & $\mathbf{R}^{2}$ & $\sigma$ \\
\hline LSDV & $\begin{array}{c}15.530 \\
(23.00)^{* *}\end{array}$ & $\begin{array}{c}-0.231 \\
(-2.82) * *\end{array}$ & $\begin{array}{c}0.495 \\
(12.4) * *\end{array}$ & $\begin{array}{l}-2.735 \\
(-2.00) *\end{array}$ & $\begin{array}{c}2.529 \\
(2.50) * *\end{array}$ & 0.980 & 0.314 \\
\hline $\begin{array}{l}\text { LSDV (with } \\
\text { time dummies) }\end{array}$ & & $\begin{array}{c}-0.197 \\
(-2.50) * *\end{array}$ & $\begin{array}{c}1.910 \\
(49.4) * *\end{array}$ & $\begin{array}{l}-2.843 \\
(-2.20) *\end{array}$ & $\begin{array}{c}3.097 \\
(2.89) * *\end{array}$ & 0.981 & 0.306 \\
\hline $\begin{array}{l}\text { Within } \\
\text { groups }\end{array}$ & & $\begin{array}{c}-0.231 \\
(-2.82) * *\end{array}$ & $\begin{array}{c}0.495 \\
(12.4) * *\end{array}$ & $\begin{array}{l}-2.735 \\
(-2.00) *\end{array}$ & $\begin{array}{c}2.529 \\
(2.50) * *\end{array}$ & 0.634 & 0.314 \\
\hline $\begin{array}{l}\text { Between } \\
\text { groups }\end{array}$ & $\begin{array}{l}7.791 \\
(0.81)\end{array}$ & $\begin{array}{l}-0.523 \\
(-1.89)\end{array}$ & $\begin{array}{c}1.138 \\
(0.420)\end{array}$ & $\begin{array}{l}-1.641 \\
(-0.74)\end{array}$ & $\begin{array}{l}4.710 \\
(0.56)\end{array}$ & 0.090 & 1.822 \\
\hline $\begin{array}{c}\text { GLS (using } \\
\text { within/between) }\end{array}$ & $\begin{array}{l}14.182 \\
(26.2)^{* *}\end{array}$ & $\begin{array}{c}-0.239 \\
(-5.17)^{* *}\end{array}$ & $\begin{array}{c}0.495 \\
(14.7)^{* *}\end{array}$ & $\begin{array}{c}-2.693 \\
(-4.37)^{* *}\end{array}$ & $\begin{array}{l}2.560 \\
(1.93) *\end{array}$ & 0.585 & 0.313 \\
\hline $\begin{array}{l}\text { GLS (using } \\
\text { OLS residuals) }\end{array}$ & $\begin{array}{l}14.189 \\
(25.9) * *\end{array}$ & $\begin{array}{c}-0.241 \\
(-5.08) * *\end{array}$ & $\begin{array}{c}0.495 \\
(14.2)^{* *}\end{array}$ & $\begin{array}{c}-2.683 \\
(-4.27)^{* *}\end{array}$ & $\begin{array}{l}2.568 \\
(1.89)\end{array}$ & 0.575 & 0.322 \\
\hline ML & $\begin{array}{c}14.183 \\
(26.2) * *\end{array}$ & $\begin{array}{c}-0.239 \\
(-5.15) * *\end{array}$ & $\begin{array}{c}0.495 \\
(14.6) * *\end{array}$ & $\begin{array}{c}-2.691 \\
(-4.35) * *\end{array}$ & $\begin{array}{l}2.561 \\
(1.93) *\end{array}$ & 0.583 & 0.314 \\
\hline
\end{tabular}

$*$ significance at $95 \% \quad * *$ significance at $99 \%$ 
Table 3

Model 2: Modeling $x$ by using hpi2

\begin{tabular}{|c|c|c|c|c|c|c|c|}
\hline & constant & tot & $\boldsymbol{e}$ & $\boldsymbol{H}$ & hpi2 & $\mathbf{R}^{2}$ & $\boldsymbol{\sigma}$ \\
\hline LSDV & $\begin{array}{l}15.420 \\
(19.9) * *\end{array}$ & $\begin{array}{c}-0.226 \\
(-2.74) * *\end{array}$ & $\begin{array}{c}0.505 \\
(10.7)^{* *}\end{array}$ & $\begin{array}{l}-2.614 \\
(-1.68)\end{array}$ & $\begin{array}{c}0.085 \\
(4.17) * *\end{array}$ & 0.980 & 0.321 \\
\hline $\begin{array}{l}\text { LSDV (with } \\
\text { time dummies) }\end{array}$ & & $\begin{array}{c}-0.199 \\
(-2.51)^{* *}\end{array}$ & $\begin{array}{c}1.915 \\
(48.2)^{* *}\end{array}$ & $\begin{array}{l}-2.779 \\
(-1.88)\end{array}$ & $\begin{array}{c}0.083 \\
(3.41)^{* *}\end{array}$ & 0.981 & 0.316 \\
\hline $\begin{array}{l}\text { Within } \\
\text { groups }\end{array}$ & & $\begin{array}{c}-0.226 \\
(-2.74) * *\end{array}$ & $\begin{array}{c}0.505 \\
(10.7)^{* *}\end{array}$ & $\begin{array}{l}-2.614 \\
(-1.68)\end{array}$ & $\begin{array}{c}0.085 \\
(4.17) * *\end{array}$ & 0.629 & 0.322 \\
\hline $\begin{array}{l}\text { Between } \\
\text { groups }\end{array}$ & $\begin{array}{l}2.898 \\
(0.15)\end{array}$ & $\begin{array}{l}-0.543 \\
(-1.99) *\end{array}$ & $\begin{array}{l}1.565 \\
(0.92)\end{array}$ & $\begin{array}{l}-1.186 \\
(-0.52)\end{array}$ & $\begin{array}{l}0.687 \\
(1.64)\end{array}$ & 0.132 & 1.805 \\
\hline $\begin{array}{c}\text { GLS (using } \\
\text { within/between) }\end{array}$ & $\begin{array}{l}14.056 \\
(24.0)^{* *}\end{array}$ & $\begin{array}{c}-0.235 \\
(-4.85) * *\end{array}$ & $\begin{array}{c}0.507 \\
(13.5) * *\end{array}$ & $\begin{array}{c}-2.553 \\
(-3.81) * *\end{array}$ & $\begin{array}{l}0.094 \\
(1.87)\end{array}$ & 0.583 & 0.322 \\
\hline $\begin{array}{l}\text { GLS (using } \\
\text { OLS residuals) }\end{array}$ & $\begin{array}{c}14.063 \\
(23.0)^{* *}\end{array}$ & $\begin{array}{c}-0.241 \\
(-4.62) * *\end{array}$ & $\begin{array}{c}0.508 \\
(12.6)^{* *}\end{array}$ & $\begin{array}{c}-2.518 \\
(-3.57)^{* *}\end{array}$ & $\begin{array}{l}0.100 \\
(1.84)\end{array}$ & 0.560 & 0.349 \\
\hline ML & $\begin{array}{l}14.056 \\
(24.0)^{* *}\end{array}$ & $\begin{array}{c}-0.235 \\
(-4.85)^{* *}\end{array}$ & $\begin{array}{c}0.507 \\
(13.6)^{* *}\end{array}$ & $\begin{array}{c}-2.553 \\
(-3.82) * *\end{array}$ & $\begin{array}{l}0.094 \\
(1.87)\end{array}$ & 0.583 & 0.322 \\
\hline
\end{tabular}

$*$ significance at $95 \% \quad * *$ significance at $99 \%$

Table 4 Model 3: Modeling $x$ by using sw2 and lw2

\begin{tabular}{|c|c|c|c|c|c|c|c|c|}
\hline & constant & tot & $e$ & $H$ & $s w 2$ & $l w 2$ & $\mathbf{R}^{2}$ & $\sigma$ \\
\hline LSDV & $\begin{array}{c}15.723 \\
(20.01)^{* *}\end{array}$ & $\begin{array}{c}-0.259 \\
(-2.67) * *\end{array}$ & $\begin{array}{c}0.491 \\
(11.7) * *\end{array}$ & $\begin{array}{l}-2.686 \\
(-1.92) \\
\end{array}$ & $\begin{array}{l}0.213 \\
(1.79)\end{array}$ & $\begin{array}{l}0.028 \\
(1.47)\end{array}$ & 0.980 & 0.317 \\
\hline $\begin{array}{l}\text { LSDV (with } \\
\text { time dummies) }\end{array}$ & & $\begin{array}{l}-0.227 \\
(-2.41)^{*}\end{array}$ & $\begin{array}{c}1.924 \\
(42.1)^{* *}\end{array}$ & $\begin{array}{l}-2.816 \\
(-2.13) *\end{array}$ & $\begin{array}{c}0.289 \\
(3.24) * *\end{array}$ & $\begin{array}{l}0.025 \\
(1.60) \\
\end{array}$ & 0.981 & 0.308 \\
\hline $\begin{array}{l}\text { LSDV (with } \\
\text { time dummies) }\end{array}$ & & $\begin{array}{l}-0.204 \\
(-2.53) *\end{array}$ & $\begin{array}{c}1.915 \\
(48.7) * *\end{array}$ & $\begin{array}{l}-2.869 \\
(-2.20) *\end{array}$ & $\begin{array}{c}0.293 \\
(3.43) * *\end{array}$ & & 0.981 & 0.308 \\
\hline $\begin{array}{l}\text { Within } \\
\text { groups }\end{array}$ & & $\begin{array}{c}-0.234 \\
(-2.81)^{* *} \\
\end{array}$ & $\begin{array}{c}0.494 \\
(12.2) * * \\
\end{array}$ & $\begin{array}{l}-2.739 \\
(-1.98) * \\
\end{array}$ & $\begin{array}{l}0.218 \\
(1.94) *\end{array}$ & & 0.631 & 0.317 \\
\hline $\begin{array}{l}\text { Between } \\
\text { groups }\end{array}$ & $\begin{array}{c}-12.997 \\
(-0.63) \\
\end{array}$ & $\begin{array}{l}-0.481 \\
(-1.77) \\
\end{array}$ & $\begin{array}{l}2.923 \\
(1.66) \\
\end{array}$ & $\begin{array}{l}-2.158 \\
(-1.02) \\
\end{array}$ & $\begin{array}{l}-0.006 \\
(-0.01) \\
\end{array}$ & & 0.120 & 1.800 \\
\hline $\begin{array}{c}\text { GLS (using } \\
\text { within/between) }\end{array}$ & $\begin{array}{l}14.221 \\
(26.1)^{* *}\end{array}$ & $\begin{array}{c}-0.243 \\
(-5.13) * *\end{array}$ & $\begin{array}{c}0.494 \\
(14.4)^{* *}\end{array}$ & $\begin{array}{c}-2.708 \\
(-4.34) * *\end{array}$ & $\begin{array}{l}0.211 \\
(1.71) \\
\end{array}$ & & 0.590 & 0.316 \\
\hline $\begin{array}{c}\text { GLS (using } \\
\text { OLS residuals) }\end{array}$ & $\begin{array}{l}14.226 \\
(25.9) * *\end{array}$ & $\begin{array}{c}-0.244 \\
(-5.05) * *\end{array}$ & $\begin{array}{c}0.494 \\
(14.0)^{* *}\end{array}$ & $\begin{array}{c}-2.703 \\
(-4.26) * *\end{array}$ & $\begin{array}{l}0.209 \\
(1.67) \\
\end{array}$ & & 0.583 & 0.324 \\
\hline ML & $\begin{array}{l}14.221 \\
(26.1)^{* *}\end{array}$ & $\begin{array}{c}-0.243 \\
(-5.13) * * \\
\end{array}$ & $\begin{array}{c}0.494 \\
(14.4)^{* *} \\
\end{array}$ & $\begin{array}{c}-2.708 \\
(-4.34) * *\end{array}$ & $\begin{array}{l}0.211 \\
(1.71) \\
\end{array}$ & & 0.583 & 0.317 \\
\hline
\end{tabular}

$*$ significance at $95 \% \quad * *$ significance at $99 \%$

Table 5 Specification Test

\begin{tabular}{|c|c|}
\hline Model 1 & $\begin{array}{c}\chi^{2}(4)=461.797 \\
(0.000) * *\end{array}$ \\
\hline Model 2 & $\begin{array}{c}\chi^{2}(4)=387.943 \\
(0.000) * *\end{array}$ \\
\hline Model 3 & $\begin{array}{c}\chi^{2}(4)=456.225 \\
(0.000) * *\end{array}$ \\
\hline
\end{tabular}



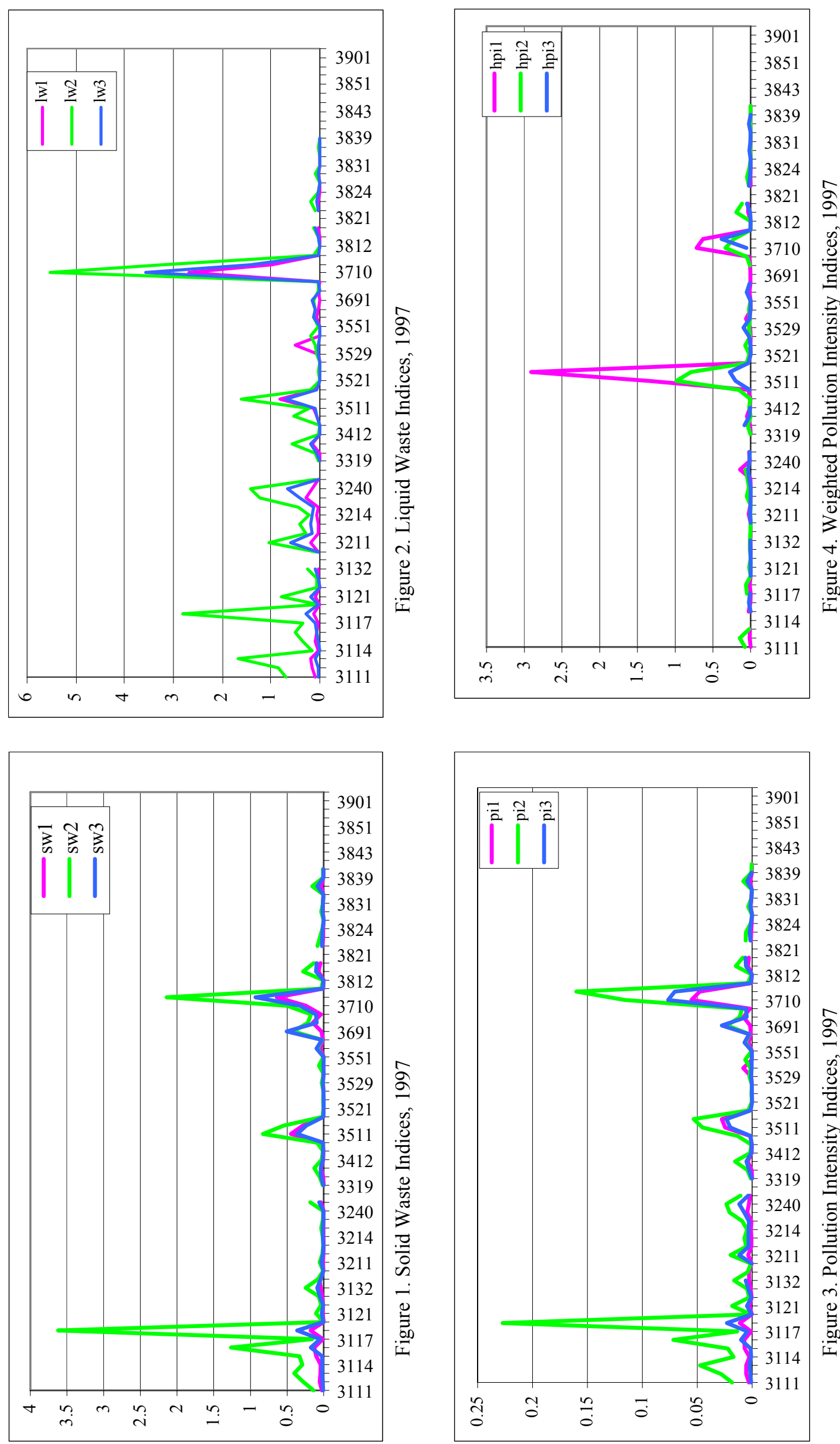